\title{
CITIZEN EMPLOYERS
}


Also By JefFrey Haydu

Making American Industry "Safe for Democracy": Comparative Perspectives on the State and Employee Representation in the Era of World War I

Between Craft and Class: Skilled Workers and Factory Politics in the United States and Britain, 1890-1922 


\section{CITIZEN

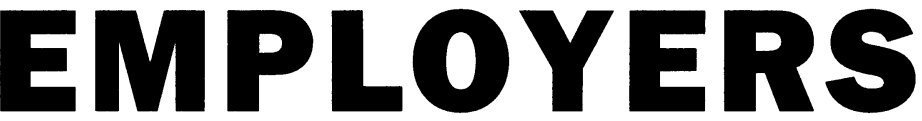

Business Communities and Labor in Cincinnati and San Francisco, 1870-1916

\section{Jeffrey Haydu}


Cornell University Press gratefully acknowledges a grant from the University of California, San Diego, which has aided in the publication of this book.

Copyright $\odot 2008$ by Cornell University

All rights reserved. Except for brief quotations in a review, this book, or parts thereof, must not be reproduced in any form without permission in writing from the publisher. For information, address Cornell University Press, Sage House, 512 East State Street, Ithaca, New York 14850.

First published 2008 by Cornell University Press

\section{Library of Congress Cataloging-in-Publication Data}

Haydu, Jeffrey.

Citizen employers : business communities and labor in Cincinnati and San Francisco, 1870-1916 / Jeffrey Haydu.

p. cm.

Includes bibliographical references and index.

ISBN 978-0-8014-4641-2 (cloth : alk. paper)

1. Industrial relations-Ohio-Cincinnati-History. 2. Industrial relationsCalifornia-San Francisco-History. 3. Middle Class-Ohio-CincinnatiHistory. 4. Middle class-California-San Francisco-History. 5. Small business-Ohio-Cincinnati-History. 6. Small business-California-San Francisco-History. 7. Labor unions-Ohio-Cincinnati-History. 8. Labor unions-California-San Francisco-History. 9. San Francisco (Calif.)-Social conditions. 10. Cincinnati (Ohio)-Social conditions. 11. United StatesSocial conditions-1865-1918. I. Title.

HD8085.C563H39 2008

$331.09771^{\prime} 7809034-\mathrm{dc} 22 \quad 2007036945$

Cloth printing

$\begin{array}{llllllllll}10 & 9 & 8 & 7 & 6 & 5 & 4 & 3 & 2 & 1\end{array}$ 
To Kath, finally 
